\title{
Eradication of metastatic mouse cancers resistant to immune checkpoint blockade by suppression of myeloid-derived cells
}

\author{
Kibem Kim ${ }^{\text {* }}$, Andrew Skora², Zhaobo Li ${ }^{2}$, Ada Tam³ ${ }^{3}$ Luis Diaz², Nickolas Papadopolous², Lee Blosser ${ }^{3}$, \\ Kenneth Kinzler ${ }^{2}$, Bert Vogelstein ${ }^{2}$, Shibin Zhou ${ }^{2}$ \\ From Society for Immunotherapy of Cancer 29th Annual Meeting \\ National Harbor, MD, USA. 6-9 November 2014
}

Recent clinical trials have shown highly promising responses in a subset of patients treated with immune checkpoint inhibitory anti-programmed cell death-1, anti-programmed cell death ligand-1 (PD-1), and anticytotoxic T-lymphocyte-associated antigen-4 antibodies (CTLA-4) [1-4]. However, immunotherapy against poorly immunogenic cancers remains a challenge. Large, modestly immunogenic CT26 tumors or poorly immunogenic metastatic $4 \mathrm{~T} 1$ tumors in mice were unresponsive to anti-PD-1 and anti-CTLA-4 treatments. Cotreatment with DNA methyltransferase and HDAC inhibitors, and checkpoint inhibitors markedly improved treatment outcomes, curing more than $80 \%$ of the tumor-bearing mice. Functional studies revealed that the primary targets of the epigenetic modulators were myeloid-derived suppressor cells (MDSCs). In addition, reduction of MDSCs using antibodies directed against them or a PI3K inhibitor that reduced circulating MDSCs had similar antitumor effects to those observed with the epigenetic modulators. Our results show that elevated myeloid-derived suppressor cells (MDSCs) are responsible for the resistance to checkpoint inhibitors and that elimination of MDSCs can lead to cures of experimental, metastatic tumors.

\footnotetext{
Authors' details

'Medical Scientist Training Program, Ludwig Center for Cancer Genetics and Therapeutics, Sidney Kimmel Comprehensive Cancer Center, The Johns Hopkins University School of Medicine, Baltimore, MD, USA. ${ }^{2}$ Ludwig Center for Cancer Genetics and Therapeutics, Sidney Kimmel Comprehensive Cancer Center, The Johns Hopkins University School of Medicine, Baltimore, MD,
}

${ }^{1}$ Medical Scientist Training Program, Ludwig Center for Cancer Genetics and Therapeutics, Sidney Kimmel Comprehensive Cancer Center, The Johns

Hopkins University School of Medicine, Baltimore, MD, USA

Full list of author information is available at the end of the article
USA. ${ }^{3}$ Department of Oncology, Sidney Kimmel Comprehensive Cancer Center, The Johns Hopkins University School of Medicine, Baltimore, MD, USA.

Published: 6 November 2014

\section{References}

1. Topalian SL, et al: Safety, activity, and immune correlates of anti-PD-1 antibody in cancer. N Engl J Med 2012, 366(26):2443-2454.

2. Brahmer JR, et al: Safety and activity of anti-PD-L1 antibody in patients with advanced cancer. N Engl J Med 2012, 366(26):2455-2465.

3. Wolchok JD, et al: Nivolumab plus ipilimumab in advanced melanoma. $N$ Engl J Med 2013, 369(2):122-133.

4. Hodi FS, et al: Improved survival with ipilimumab in patients with metastatic melanoma. N Engl J Med 2010, 363(8):711-723.

doi:10.1186/2051-1426-2-S3-P267

Cite this article as: Kim et al.: Eradication of metastatic mouse cancers resistant to immune checkpoint blockade by suppression of myeloidderived cells. Journal for ImmunoTherapy of Cancer 2014 2(Suppl 3):P267.

Submit your next manuscript to BioMed Central and take full advantage of:

- Convenient online submission

- Thorough peer review

- No space constraints or color figure charges

- Immediate publication on acceptance

- Inclusion in PubMed, CAS, Scopus and Google Scholar

- Research which is freely available for redistribution 
